\title{
Meteorological and water quality changes in Lake Trasimeno (Umbria, Italy) during the last fifty years
}

\author{
Alessandro LUDOVISI* and Elda GAINO \\ Dipartimento di Biologia Cellulare e Ambientale, Università degli Studi di Perugia, Via Elce di Sotto - 06123 Perugia, Italy \\ *e-mail corresponding author: alessandro.ludovisi@unipg.it
}

\begin{abstract}
This paper illustrates the results of an analysis performed on historical data of the main meteorological and water quality variables collected during the last fifty years in the basin of Lake Trasimeno, a shallow lake subjected to important water level fluctuations. The results reveal a significant increase of the annual mean of minimum and maximum air temperature, water temperature and solar radiation, and a significant reduction of precipitation and cloud cover, which have mostly occurred during the last twenty years. The decadal rate of warming observed in the last twenty years for air temperature $\left(0.33{ }^{\circ} \mathrm{C}\right.$ decade $\left.e^{-1}\right)$ is consistent with the estimate reported by the IPCC for the land-surface temperature in the Northern Hemisphere, whereas the surface water temperature in Lake Trasimeno shows a more marked increase $\left(0.65{ }^{\circ} \mathrm{C}\right.$ decade $\left.{ }^{-1}\right)$, comparable to that observed in other lakes of Mediterranean areas. On a monthly scale, the most significant variations are observed in late-spring and early summer months for temperature and solar irradiation, and in winter and spring months for rainfall, which result in an appreciable modification of the seasonal progression. The alterations of the thermal and hydrological balance of the lake have caused a progressive lowering of the water level and the emergence of evaporative conditions. As a consequence of the drought, a progressive accumulation of dissolved salts $\left(3.510^{6} \mathrm{~kg} \mathrm{y}^{-1}\right)$ is observed, which is partially explained by meteoric loading. The analysis also shows that an increase in the total alkalinity has occurred during the main drought phases of the last forty years, which has been shown to be consistent with what expected on the basis of the changes in the ionic composition of the waters. With decreasing water levels, a strong reduction in water transparency has also been observed, which does not appear to be connected with a change in the trophic state of the lake, but rather with the increase of suspended solids from bottom sediments, in agreement with the predictions based on resuspension models in shallow waters. On putting the results into the future scenario of climate change, an accelerating drought and progressive worsening of the water quality can be predicted for Lake Trasimeno in the near future.
\end{abstract}

Key words: LTER, shallow lakes, drought, climate change, salinisation

\section{INTRODUCTION}

Shallow-water ecosystems are widespread worldwide. They often represent regional "hot spots" of biodiversity and are subject to conservation policies. Climate change can exert severe impacts on the functioning of these systems, as their hydrological, thermal and hydrochemical regime are strongly affected by meteoclimatic variations. In a number of these ecosystems, problems related to the current climate change (drought, flood, warming, salt accumulation, water quality changes, etc.), often amplified by water use and pollution, have been experienced over the last few decades (Bates et al. 2008). The impact of drought has been particularly severe in Central Africa (e.g., Lake Chad and Lake Tonga: UNEP 2006), Southeastern Europe (e.g., Lake Balaton and Lake Velence: Wantzen et al. 2008) and Southeastern Australia (e.g., Lake George: Beeton et al. 2006), where the drought risk has been estimated to be more significant at a planetary level (Bates et al. 2008).

Drought in standing water bodies occurs as stream inputs and surface runoff decline and, as it is usually associated with high temperature, evaporation may increase sharply. The effects of drought on water quality may be more or less evident, depending on the hydrological and hydrochemical regime of the water basin. They may however be expected to increase rapidly as the system approaches evaporative conditions (closed basin and water losses exceeding water supplies). In these conditions, the water level decreases and the accumulation of salt and nutrients is favoured. In shallow waters, water lowering is generally accompanied by an increase in water turbidity, due both to increasing phytoplankton density and resuspended sediments (Scheffer 1998). With stagnant conditions, nutrients may build up increasing the risk of blooms of toxic blue green and golden algae, thus causing a decrease in oxygen levels and stress on aquatic fauna (e.g., Colley 2004). As drought progresses, water levels recede from the normally highly productive littoral zone, stranding some of the fauna and flora, such as mussels (Balogh et al. 2008) and rooted aquatic macrophytes (Furey et al. 2006). The study of the effect of climatic changes on shallow lakes is therefore of relevance both from a scientific, a conservation and a health point of view.

Lake Trasimeno (Umbria, Italy) is a shallow lake of a remarkable naturalistic importance (Site of Community Interest, Special Protection Zone and Regional Park). Despite its large extension (about $124 \mathrm{~km}^{2}$ ) the 
lake is very shallow and its bathymetry very smooth, with a maximum nominal depth of $6.3 \mathrm{~m}$, which can only be reached when the water level exceeds the artificial outlet threshold located, since 1983, at $257.50 \mathrm{~m}$ a.s.l. The catchment basin of the lake (Fig. 1) lies over a substratum of low permeability (turbidite), covered by Plio-Pleistocene and Holocene deposits, with a variable content of silicatic and of carbonatic minerals (Deffenu \& Dragoni 1978; Dragoni 1982, 2004).

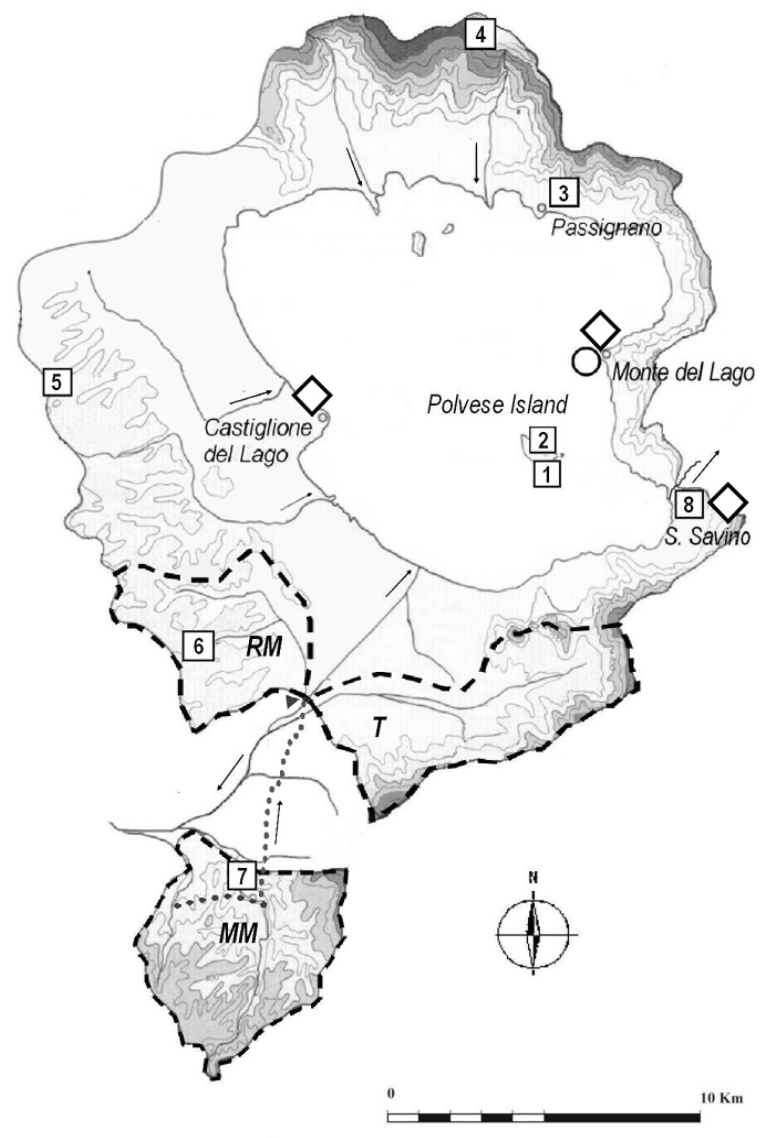

Fig. 1. Lake Trasimeno and its catchment basin (modified from Orsomando \& Catorci 1991). The dashed line outlines the areas added to the watershed in the years 1957-62: T Tresa river basin; RM - Rigo Maggiore river basin ( $\mathrm{T}$ and RM were part of the natural basin of the lake before 1482); MM Moiano and Maranzano river basin (this basin is joined to the lake by a man-made canal crossing over the natural waterways - dotted line). The map shows the location of the Hydrobiology Station of the University of Perugia (circle), the longterm meteorological stations considered in the present investigation (diamonds) and the automatic meteorological stations of the S.I.G.L.A. (Informative Agricultural Management System of the Perugia Province) monitoring system (squares).

Because of its small extension $\left(383 \mathrm{~km}^{2}\right)$ relatively to the lake area, the water balance of the lake is strongly affected by the pluviometric regime, and annual water inflows are frequently lower than evaporation losses (Ludovisi 1998; Dragoni 2004). The strict dependence of the water balance on meteorological conditions has caused dramatic floods and droughts over the centuries and human interventions have been made in order to regulate the lake level since Etruscan or Roman times. Starting from the Middle Ages, there is a fair amount of documentation on works regarding the hydraulic regulation of the lake (Dragoni 2004; Gambini 1995). The outlet restructuring, completed at the end of the 19th century, gave inception to a progressive lowering of the lake level which led to a dramatic crisis of the 1950 s, to which contributed several variations of the artificial outlet threshold (Fig. 2). The enlargement of the catchment basin performed in 1957-62 (Fig. 1), allowed the lake to rapidly recover from drought. However, the "Lake Trasimeno problem", at present consisting of a phase of very low levels - to which the withdrawals for agricultural and civil use have contributed (Morozzi et al. 1998) - still remains unsolved, mainly because the regulation works and restriction rules on withdrawals recently adopted seem to be ineffective in the current climate change phase (Dragoni et al. 2003). The rapid sequence of fluctuation in the water level, in combination with the change in the meteorological and atmospheric forcing that has occurred in the last few decades, have arguably caused significant effects on the water quality as well as on the biocoenotic composition of the lake. In addition, these effects may be expected to overlap and interact with those due to chemical loadings from the watershed, particularly during drought phases. However, a thorough evaluation of the impact on water quality of such a multiple forcing has not been made yet.

In the present work, the trend of the main meteorological forcing variables and water quality variables during the last few decades is reconstructed on the basis of data collected in the lake basin since 1950, with the aim of identifying the most critical issues emerging in the lake in relation with current and predictable anthropogenic impacts.

This research forms part of the National project M.I.C.E.N.A. (Modello Integrato per l'Evoluzione degli Ecosistemi Naturali e Agricoli in relazione ai cambiamenti climatici nell'area mediterranea), which is aimed to understand the impact of climate change on natural and agricultural systems in the Mediterranean areas, and to provide integrated models of sustainable development.

\section{METHODS}

\subsection{Meteorological data}

The fifty-year long meteorological series analysed in this study have been collected daily at a public thermopluviometrical station (at present managed by the Umbria Region) located in Monte del Lago, in front of the Hydrobiology Station of the University of Perugia (Fig. 1), since 1951. Precipitation and min-max air temperature data were extracted from the yearbooks (Annali Idrologici) published by the Italian Ministero dei Lavori Pubblici - Servizio Idrografico. Fifty-year long series collected in the nearby meteorological stations located 


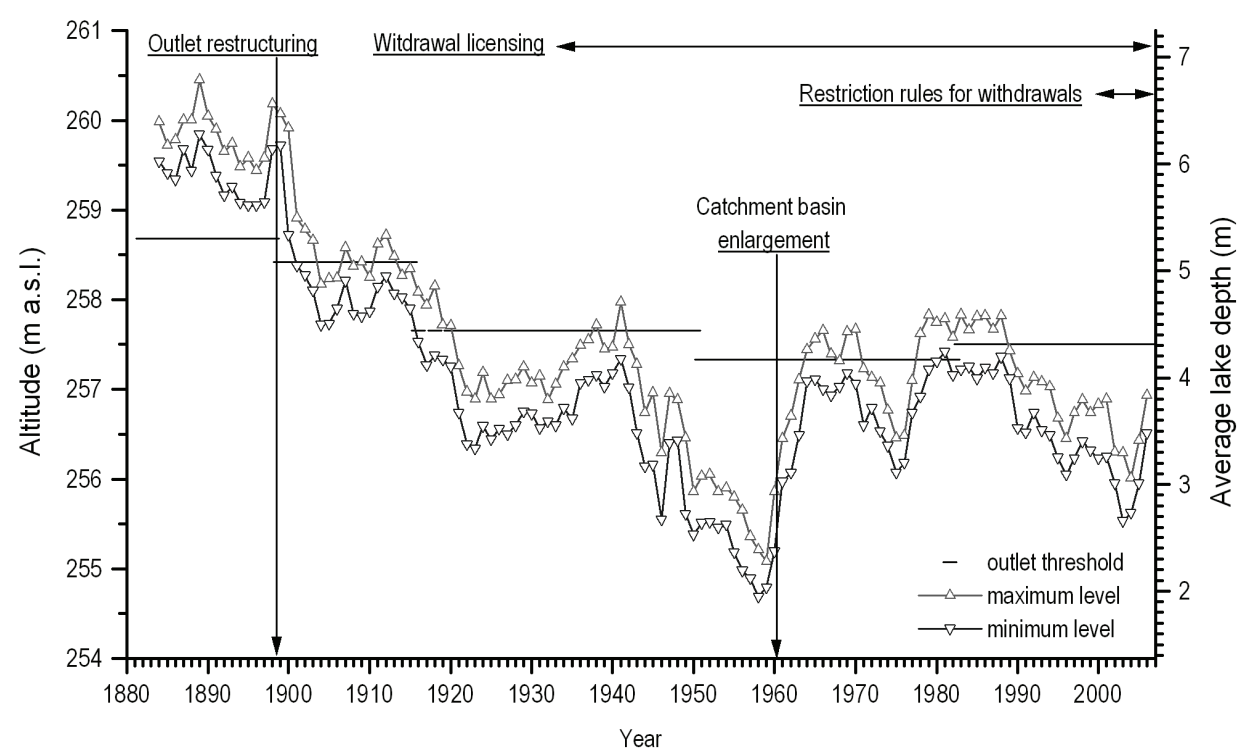

Fig. 2. Trends of the annual maximum and minimum levels of Lake Trasimeno and main water management intervention from 1884 to 2006 (from Gambini 2000, modified).

in S.Savino and Castiglione del Lago (Fig. 1), and more recent meteorological series (years 1988 -2006) automatically collected every 30 minutes in the stations of S.I.G.L.A. (the Informative Agricultural Management System of the Perugia Province - Fig. 1) were also organised and examined in order to validate and complete the series collected at Monte del Lago. The quality of long-term series of precipitation and air temperature collected at Monte del Lago was first checked by performing a cross control against the data series collected at S. Savino and Castiglione del Lago. After the removal of evident erroneous data, monthly series were calculated for the three stations and then their homogeneity was tested by applying Craddock's homogeneity test (Craddock 1979), under the hypothesis of the constancy of precipitation ratios and temperature differences (Brunetti et al. 2006). The test was performed in two ways: a) testing each series against the others by a multiple application of the test (no reference series is assumed); b) assuming as a reference the series collected at a meteorological station located in the city of Perugia, which has been previously tested for being included in an Italian homogenised data set (Brunetti et al. 2006).

For precipitation, the test showed a good level of homogeneity for all the series, with the precipitation ratios ranging from 0.99 to 1.0 (test $a$ ) and from 0.86 and 0.87 (test $b$ ). After the check, the series of Monte del Lago was completed by replacing the missing data (14\% of the total) by those collected at the station of S. Savino, whose series showed the highest similarity with that collected at Monte del Lago (the difference between the daily values is normally distributed around an average value of $-0.02 \mathrm{~mm}-\mathrm{N} \sim 12000$ ).

The application of Craddock's test to daily maximum and minimum air temperature revealed evident break signals in the series before 1960. The removal of the data collected in the period 1951-1959 significantly improved the results of the test applied (test $a$ and $b$ ). The monthly series of maximum and minimum daily temperatures recorded since 1988 at a S.I.G.L.A. station located at Polvese Island (station n. 1 - Fig. 1) were also tested for homogeneity, and the homogenised data were used to complete the series of Monte del Lago, which showed several interruptions (by a total of $11 \%$ missing data) in period 1990-2006.

Other recent series of meteorological data collected in the S.I.G.L.A. stations were organised, cross-checked for homogeneity and examined. Here we briefly report the 1988-2006 trend for the meteorological variables (solar radiation, wind speed and relative humidity) that are mostly connected with the hydrological balance and the mixing of the lake waters. The data series examined were gathered in the stations n. 1 and 2, located at the Polvese Island (Fig. 1).

\subsection{Water temperature}

The temperature of the lake waters has been measured at surface by a mercury thermometer in front of the Hydrobiology Station (Fig. 1) since June 1965. The water temperature data here presented were directly extracted from a logbook filled in by the technicians working at the Station. Three data series were available:

- Series 1: June 1965 - February 1990 - Daily measurement at 9:00 a.m.;

- Series 2: February 1988 - May 1993 -Weekly measurement at 11:00 a.m.;

- Series 3: June 1992 - August 2006-Daily measurement at 11:00 a.m..

The correlation between the series was evaluated by considering time-overlapping data $\left(r^{2}{ }_{\text {Series } 1 / \text { Series } 2}=0.988\right.$, 

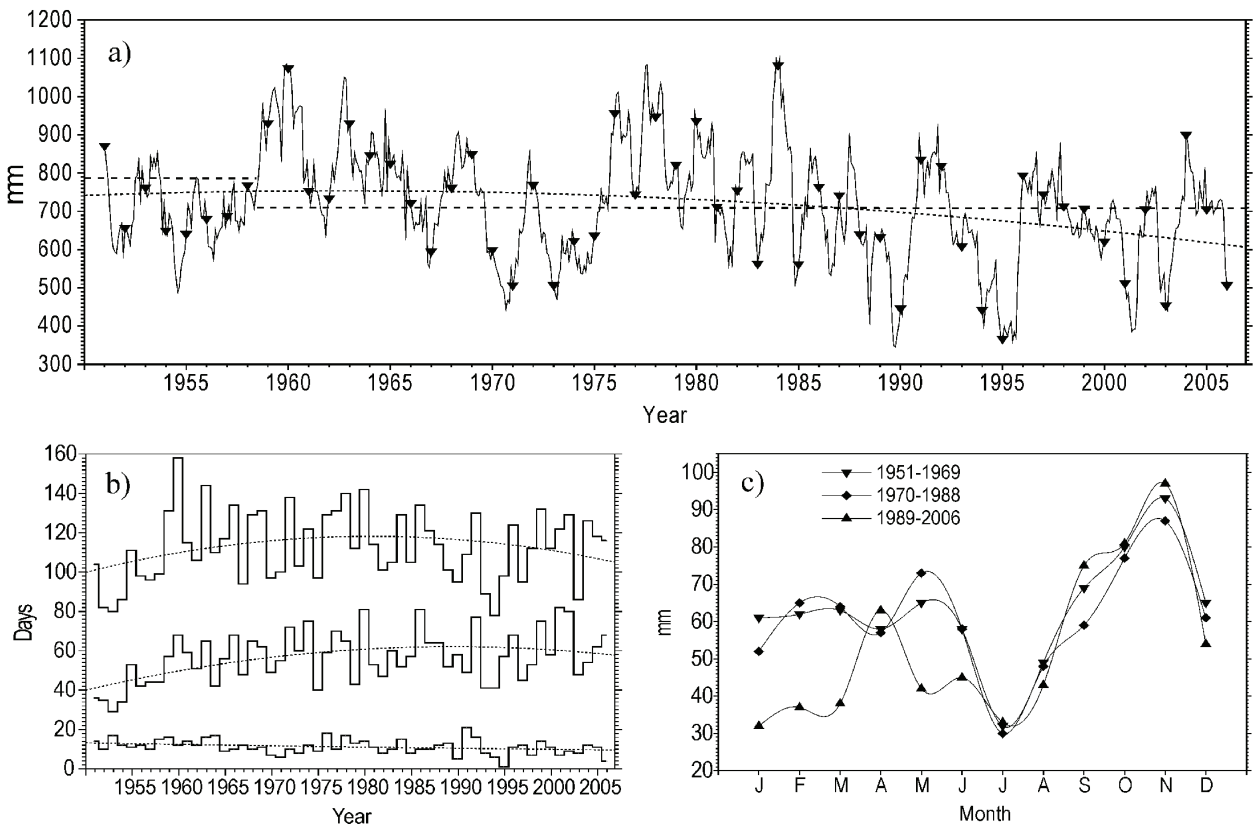

Fig. 3. Precipitations at Lake Trasimeno from 1951 to 2006, based on daily data collected at Monte del Lago: a) annual monthly moving average precipitation. The dotted line shows the best quadratic fitting curve. The dashed line indicates the critical annual rainfalls for the lake as estimated by Dragoni (1982); b) number of rainy days: total number (top), number of days with an amount of precipitations under the $50^{\text {th }}$ percentile (middle) and number of days with precipitations an amount of precipitations above the $90^{\text {th }}$ percentile (bottom); c) distribution of monthly precipitations during three selected periods.

$\left.\mathrm{N}=108 ; r_{\text {Series2/Series3 }}^{2}=0.974, \mathrm{~N}=37\right)$ and a linear regression $\left(\mathrm{T}_{\text {Series2 a.m. }}=1.055+0.994 \mathrm{~T}_{\text {Series } 1} ; \mathrm{S} . \mathrm{E}_{\mathrm{yx}}=\right.$ 0.55) was used to transform the data of the Series 1 into a series comparable to the subsequent series collected at 11:00 a.m..

\subsection{Water quality}

The historical analysis was mainly focused on a limited number of water quality data - water transparency (as Secchi depth), total phosphorus (TP), soluble reactive phosphorus (SRP), dissolved oxygen (DO), $\mathrm{pH}$, total alkalinity (TA), water conductivity at $25{ }^{\circ} \mathrm{C}$ and several major ions $\left(\mathrm{Cl}^{-}, \mathrm{SO}_{4}{ }^{2-}, \mathrm{Ca}^{2+}, \mathrm{Mg}^{2+}\right)$ - representative of the surface waters of the littoral areas located in front of Monte del Lago (Fig. 1), for which significant long-term time series were available.

Water quality data collected before 1990 were extracted from publications reporting the results of a number of sampling surveys carried out in front of the Hydrobiology Station since 1950s (Moretti 1958; Mannelli \& Mancini 1962; Tiberi et al. 1971, 1973; Di Giovanni et al. 1974; Trevisan 1978; Taticchi \& Tiberi 1980; Tiberi 1980, 1985; Gianotti et al. 1982; Mearelli 1985; Franconi et al. 1987; Mantilacci et al.1990; Mearelli et al. 1990). Most of the sampling surveys were performed annually with a monthly sampling frequency, in sites located between 150-300 $\mathrm{m}$ from the shoreline. Only the data collected in sites $>2 \mathrm{~m}$ in depth were included in the data set examined. The analytical methods used in the considered investigations complied with APHA-AWWA-WPCF's "Standard Methods for the Examination of Water and Wastewater" (various editions).

Recent water quality data (years 1990-2006) were extracted from a dataset, provided by A.R.P.A. Umbria (the Regional Environmental Protection Agency of Umbria), collected during the Monitoring Programme for the Control of Eutrophication, in a site (Albaia) located at about $1 \mathrm{~km}$ north of the Hydrobiology Station. In addition to the previously quoted variables, the monitored variables included chlorophyll- $a$, total dissolved solids (TDS - gravimetrical), nitrates, nitrites and ammonia. The analytical protocols adopted in the programme complied with CNR-IRSA's methods (see, e.g., CNR-IRSA 1994 and APAT-CNR-IRSA 2003). A thorough examination of the analytical methods used in different periods drove us to omit the examination of the long term trend of some important ionic species, such as reactive silica, nitrates, nitrites and ammonia, as the comparability of the data series was not assured. From the prepared database, annual maximum and minimum were extracted and annual mean was calculated from the seasonal means when a minimum of 2 values for each season was available.

\section{RESULTS}

\subsection{Meteorology}

Precipitation - During the last fifty years, the annual precipitation has shown a marked variability (from 345 in 1989 to $1100 \mathrm{~mm}$ in 1984) around an average value of $716 \mathrm{~mm} \mathrm{y}^{-1}$ (Fig. 3a). This value is very close to the 

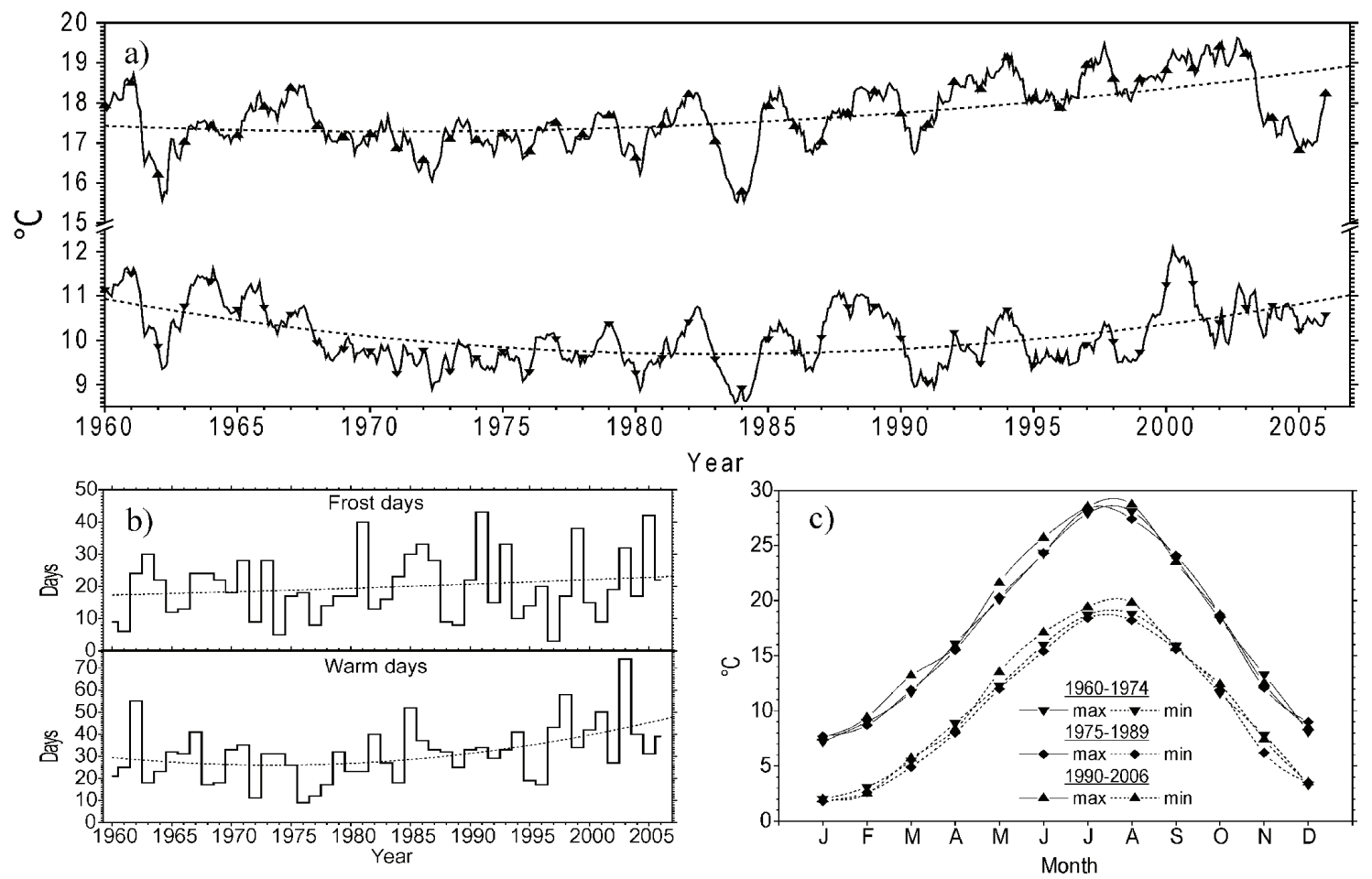

Fig. 4. Air temperature at Lake Trasimeno from 1960 to 2006, based on daily data collected at Monte del Lago: a) annual monthly moving average of maximum $(\boldsymbol{\Delta})$ and minimum $(\boldsymbol{\nabla})$ air temperature (the dotted lines show the best quadratic fitting curves); b) number of frost days (days with minimum temperature below $0^{\circ} \mathrm{C}$ ) and number of warm days (days with maximum temperature above the $90^{\text {th }}$ percentile $-29^{\circ} \mathrm{C}$ ). The dotted lines show the best quadratic fitting curves; c) distribution of monthly average maximum and minimum air temperature during the three selected periods.

critical rain $\left(788 \mathrm{~mm} \mathrm{y}^{-1}\right.$ for the years 1951-58 and 709 $\mathrm{mm} \mathrm{y}^{-1}$ for the subsequent period), which represents the precipitation necessary to balance evapo-transpiration and withdrawals (Dragoni 1982). By comparing annual rainfall with water level fluctuations (Fig. 2), it is evident that annual precipitations below the critical values (years 1955-1958, 1970-1975, 1988-1990, 1993-1996 and 2000-2003) resulted in a rapid decrease of the water level. The enlargement of the catchment basin, completed at the end of the $1950 \mathrm{~s}$, has significantly reduced the risk of water level lowering during the subsequent three decades. Starting from the end of the 1980s, however, yearly precipitations have been frequently below the critical value, so that the level of the lake has progressively decreased. The total number of wet days per year does not show (Fig. 3b) a significant reduction in the period 1951-2006, but the intensity of precipitations shows a decreasing trend: the number of days with rainfall below the 50th percentile $\left(<3 \mathrm{~mm} \mathrm{~d}^{-1}\right)$ shows a significant increase, particularly in 1950s and 1960s, whereas the number of days with intense rains (above the 90 th percentile, i.e. $>16.8 \mathrm{~mm} \mathrm{~d}^{-1}$ ) shows a slightly decreasing trend (Fig. 3b). However, one of the most significant changes in precipitation deals with the seasonal distribution. The comparison of the trend of monthly rainfall, clustered in three different periods (1951-69; 1970-1988; 1989-2006), shows that the last period significantly differs from the others (Fig. 3c), as also confirmed $(p<0.05)$ by the application of the multivariate Student's $t$-test (Hotelling $T$-square test). The application of uni-variate Student's $t$-test showed that the monthly precipitations are significantly different $(p$ $<0.05$ ) in the first half of the year (January to May), with the exception of April. In seasonal terms, the precipitation decreased by about $15 \%$ in winter (DecemberJanuary-February, from now DJF), $24 \%$ in spring (March-April-May, from now MAM) and $11 \%$ in summer (June-July-August, from now JJA) with respect to the previous periods. By contrast, precipitations remained almost unchanged in autumn $(+4 \%)$.

\subsubsection{Air temperature}

The trend of maximum and minimum daily temperatures (Fig. 4a) shows a concavity with a minimum localised in the late 1970s - early 1980s, which is more curved for the data of minimum temperature. The fitted curves, both statistically significant $(p<0.05)$, show a clear increasing trend starting from the beginning of the 1980 s, which allows an increase of about 1.6 and $1.2{ }^{\circ} \mathrm{C}$ respectively for the maximum and minimum temperature to be estimated for the last thirty years. The number of frost days per year did not show a significant $(p$ $>0.05)$ variation, whereas a significant $(p<0.01)$ increase in the number of warm days can be estimated on the basis of the regression curve (Fig. 4b). The curve is strongly affected by the extremely high number of 

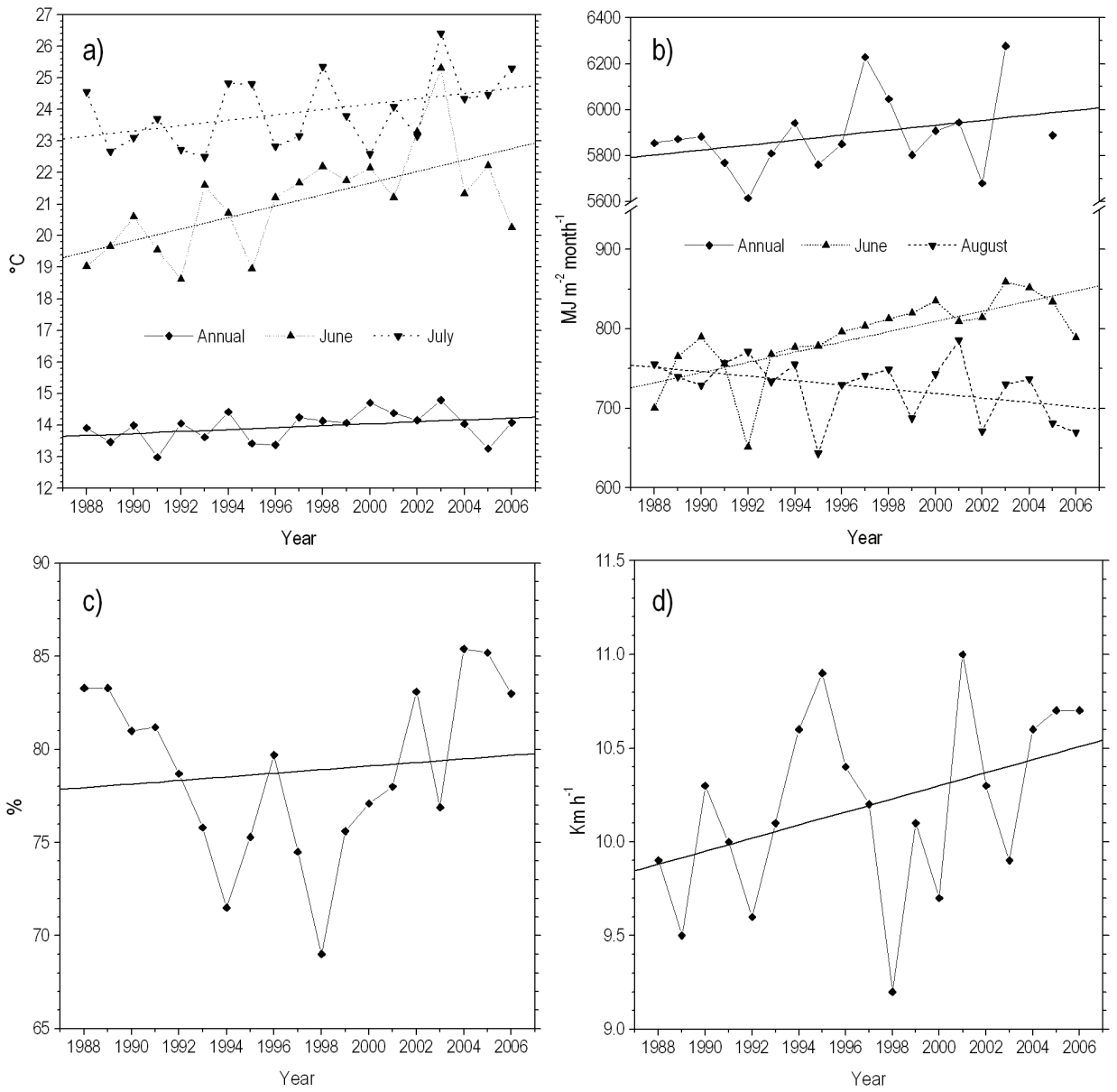

Fig. 5. Trends of the annual and some selected monthly means of air temperature (a), solar radiation (b), relative humidity (c) and wind speed (d) from 1988 to 2006, based on data collected at the S.I.G.L.A. meteorological stations.

warm days observed during the "heat wave" of summer 2003. The comparison of the trend of monthly maximum and minimum temperature, clustered in three different periods (1960-74; 1975-1989; 1990-2006), shows that the latter differs from the others, especially during the spring and summer months (Fig. 4c). Hotelling's $T$ square test applied to the three aggregated sets of data confirmed that, whereas the first two period are statistically homogeneous, the seasonal progression of temperature (both maximum and minimum) in the period 1990-2006 was statistically different from the others ( $p$ $<0.06$ ). The uni-variate Student's $t$-test showed that monthly maximum air temperatures were significantly higher $(p<0.05)$ in the months ranging from May to August, with the difference ranging from +1.21 to +2.05 ${ }^{\circ} \mathrm{C}$. As far as minimum air temperature is concerned, a statistically significant difference $\left(p<0.05 ;+0.9{ }^{\circ} \mathrm{C}\right)$ was observed for the month of June. In seasonal terms, these changes resulted in an increase of the maximum air temperature of about $1.5^{\circ} \mathrm{C}$ during spring (MAM) and summer (JJA), and an increase of minimum air temperature of about $0.7^{\circ} \mathrm{C}$ in summer.

The analysis of the air temperature data collected half-hourly at the meteorological station located at the
Polvese Island showed that the annual mean air temperature increased by about $0.6{ }^{\circ} \mathrm{C}\left(0.33{ }^{\circ} \mathrm{C}\right.$ decade $\left.^{-1}\right)$ in the period 1988-2006 (Fig. 5a), although the linear trend is not highly significant $(p=0.13)$. A more significant increasing trend was observed for the late spring and early summer months (April-July), with particular reference to June $(p=0.004)$ and July $(p=0.06)$, for which an increase of about 2.4 and $1.5{ }^{\circ} \mathrm{C}$ can be estimated respectively (Fig. 5a). In seasonal terms, these variations resulted in an average increase of the water temperature of about $1.3{ }^{\circ} \mathrm{C}$ during spring (MAM) and $1{ }^{\circ} \mathrm{C}$ in summer (JJA).

\subsubsection{Solar radiation}

The analysis of the data series of the incoming solar radiation showed that, although the linear trend is not very significant $(p=0.19)$, the total annual irradiance slightly increased in the period 1988-2006 (Fig. 5b). On a monthly scale, a regression analysis revealed that the variation in the incoming solar radiation is not significant for most months, with the exception of late springearly summer months (April-July). The trend is particularly significant for June $(p<0.001)$, for which an increase of about $15 \%$ can be estimated (Fig. $5 b$ ). On 

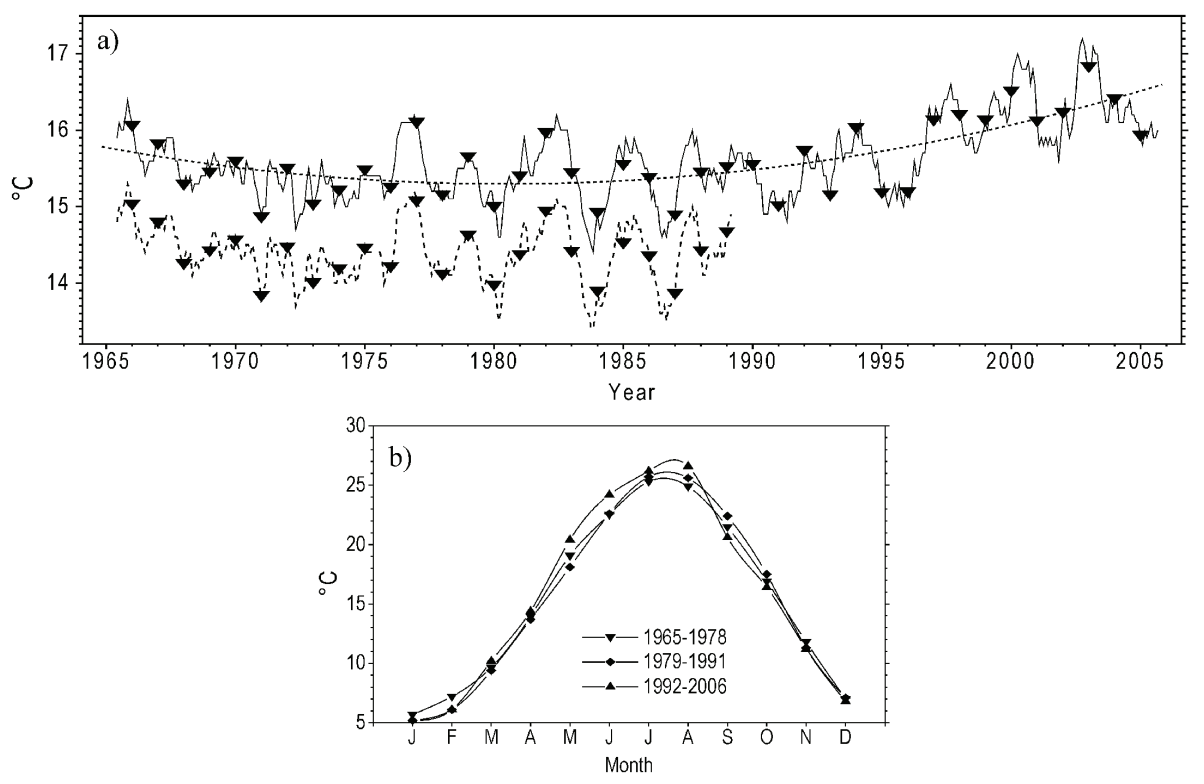

Fig. 6. Surface water temperature at 11:00 a.m. in Lake Trasimeno from 1965 to 2006, based on the three series of data collected at Monte del Lago: a) annual monthly moving average of the surface water temperature (the dotted line shows the best quadratic fitting curve. The trend of the original data series collected at 9:00 a.m. on the basis of which the series at 11:00 a.m. was reconstructed for the period 1965-1990 is also shown (dashed line); b) distribution of monthly average surface water temperature of Lake Trasimeno in the three selected periods.

the other hand, a fairly significant $(p=0.08)$ decreasing trend is shown by August, with a consequent depletion of about $7 \%$ of the incoming radiation. On the basis of the Savinov-Angstrom equation (Budyko 1974), the corresponding fraction of sky covered by clouds can be estimated to decrease from 40 to $23 \%$ in June and to increase from 18 to $28 \%$ in August.

As far as the other meteorological variables examined - relative humidity and wind speed - are concerned, a relatively marked inter-annual variability was observed (Figs 5c, d), but no statistically significant trend was evidenced in the annual and monthly series.

\subsection{Water temperature}

Similarly to air temperature, the reconstructed trend of surface water temperature in Lake Trasimeno at 11:00 a.m. shows (Fig. 6a) a concavity with minima localised in the late 1970s - early 1980s. After a slight decrease during the late 1960s, the annual average temperature of the lake fluctuated around a value of about $15.5^{\circ} \mathrm{C}$ up to the early $1990 \mathrm{~s}$, after which it increased steeply. The comparison of the monthly average temperature, clustered in three different periods (1965$1978 ; 1979-1991 ; 1992-2006)$, shows that the period 1992-2006 differs from the other ones (Fig. 6b), especially during the spring and summer, as confirmed by the multivariate Hotelling $T$-square test $(p<0.08)$. The application of univariate Student's $t$-test showed that only the temperature of May, June and August, are highly statistically different $(p<0.02)$, the differences being $+1.8,+1.6$ and $+1.4{ }^{\circ} \mathrm{C}$ respectively. In seasonal terms, an average increase of the water temperature of about $1.3{ }^{\circ} \mathrm{C}$ during spring (MAM) and $1{ }^{\circ} \mathrm{C}$ in summer (JJA) can be estimated. As shown by Ludovisi (1998) the series of data collected at 11:00 a.m. can be taken as representative of the mean daily temperature, with an average error of $4 \%$. Therefore, on the basis of the observed trend, the rate of increase of surface water temperature can be estimated of the order of $0.65{ }^{\circ} \mathrm{C}$ decade $^{-1}$ for the period 1988-2006.

No significant long-term data series concerning the depth profile of water temperature were available for Lake Trasimeno. As results from literature data (Tiberi et al. 1971; Trevisan 1978; Mantilacci et al. 1990) and from the examination of the data collected by A.R.P.A. Umbria, no real thermal stratification has been observed during the last four decades, although vertical gradients of a small extent (about $1-2{ }^{\circ} \mathrm{C}$ between surface and bottom layers) have been occasionally observed during the summer period.

\subsection{Water quality}

The long-term trend of the environmental variables most continuously monitored in the surface waters of Lake Trasimeno is shown in figure 7. As can be seen, the annual maxima, minima and means of water transparency have been subjected to consistent and significant fluctuations, up to $2 \mathrm{~m}$ in amplitude, during the period considered (only minima values were available after 1993, because the monitoring protocol of A.R.P.A. Umbria applied a higher threshold of $1.2 \mathrm{~m}$ ). Very low values were detected in the periods 1958-60, 1973-75 and 1989-2006, when the lake has experienced the most significant water lowering of the last decades (Fig. 2). 

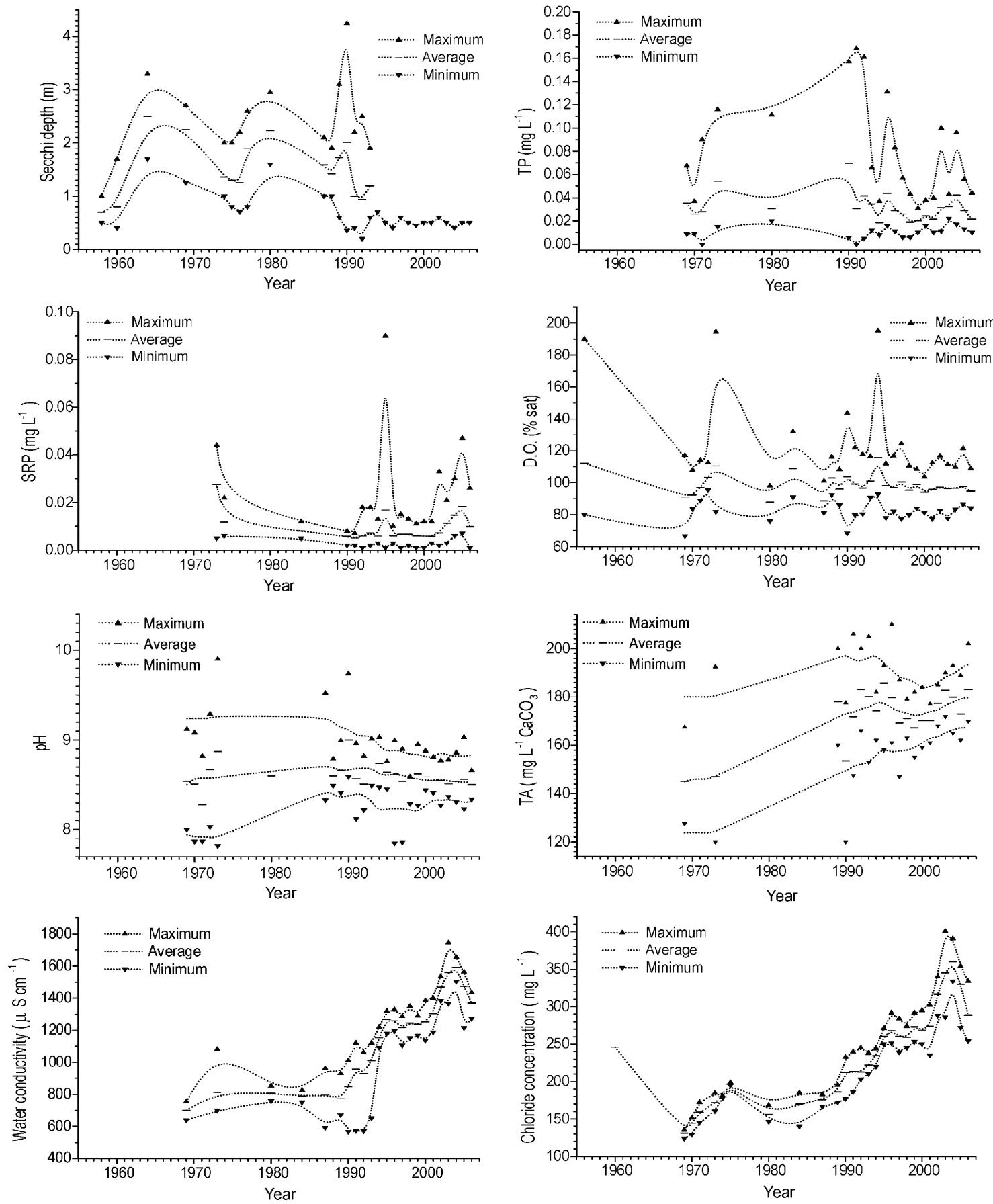

Fig. 7. Trends of the annual maximum, mean and minimum of several water quality variables measured in the surface waters of Lake Trasimeno from 1956 to 2006.

Such a behaviour, however, is very difficult to explain in terms of variation in the trophic state of the lake: in fact, on the basis of the data collected in the last two decades, the correlation between water transparency and chlorophyll- $a$ or total phosphorus (TP) concentration (after log-log transformation) is quite poor (chlorophyll- $a: r^{2}=0.28 ; p<0.001 ; \mathrm{N}=101-\mathrm{TP}: r^{2}=0.05 ; p$ $=0.013 ; \mathrm{N}=129)$. The correlation is particularly weakened by winter data, which often represented annual minima of transparency. On a fifty-year time scale, the annual mean of the TP concentration varied moderately around the 'boundary value' of $0.035 \mathrm{mg} \mathrm{L}$, which separates the mesotrophic from the eutrophic class, according to the criteria adopted by the OECD (Vollenweider \& Kerekes 1982), but no clear long-term trend can be envisaged (Fig. 7). Similar responses were obtained when considering the data of chlorophyll- $a$ concentration collected in the last two decades: the mean annual concentration of chlorophyll- $a$ varied between 2.3 and $14.4 \mu \mathrm{g} \mathrm{L}^{-1}$, with annual maxima 
ranging from 7 to $55 \mu \mathrm{g} \mathrm{L}{ }^{-1}$. Apart from a few cases, the concentration of soluble reactive phosphorus (SRP) has slightly exceeded the analytical threshold of $1 \mu \mathrm{g} \mathrm{L}^{-1}$ during the last forty years (Fig. 7). Such a low concentration has certainly been limiting for algal growth, the ratio N/P being mostly in excess $(70 \%$ of the cases in the period 1990-2006) of the theoretical value of 7.2 suggested by ILEC-UNEP (1989). Among the other variables usually connected with the trophic state, dissolved oxygen (DO) does not show any significant pattern of variations (Fig. 7). The annual mean of DO at the surface varied slightly around the saturation value, with annual maxima and minima generally deviating less than $20 \%$ from the mean value. Occasionally, very high values have been recorded, as in late summer 1956, 1973 and 1994.

The seasonal pattern of $\mathrm{pH}$ has followed the typical behaviour observed in calcareous freshwater lakes, with minima mostly localised in December and maxima in September, when the value occasionally approached 10 $\mathrm{pH}$ units (Fig. 7). The annual mean values of $\mathrm{pH}$ lay between 8.2 and $8.9 \mathrm{pH}$ units, without showing any clear long-term trend, but a marked reduction (about 0.6 $\mathrm{pH}$ units) in the annual range of $\mathrm{pH}$ can be observed when comparing the data of the period 1969-1973 with those of the recent years. This would suggest that the buffer capacity of the waters underwent a significant increase. This hypothesis is supported by the change in the total alkalinity (TA), whose annual means were about $30 \mathrm{mg} \mathrm{L}^{-1} \mathrm{CaCO}_{3}$ lower in the period 1969-1973 than in the period 1987-2006 (Fig. 7). An increasing trend can be also envisaged in the last decades, which is particularly clear for the annual minima.

However, the most evident changes in the water quality of Lake Trasimeno during the last decades deal with salt concentration. The total concentration of dissolved solids (TDS) has shown significant long-term variations as well as seasonal fluctuations, which were strictly linked with the meteorological and hydrological events. When the renewal of the waters was hampered (i.e., when the water level lay below the outlet threshold), TDS fluctuated significantly during the year, as a consequence of the concentration/dilution process due to the seasonal variations in the lake volume $\left( \pm 5810^{6}\right.$ $\mathrm{m}^{3}$ on average over the last 20 years). In particular, during the last 20 years, the extent of the seasonal change in TDS has been of the order of $100 \mathrm{mg} \mathrm{L}^{-1}$, or $280 \mu \mathrm{S} \mathrm{cm}^{-1}$ in terms of water conductivity (Fig. 7), usually being a maximum in late summer and a minimum after the autumn rainfall. The available historical data allowed us to partially reconstruct the inter-annual trend of salt content before the end of 1980s. Water conductivity and chloride concentration (Fig. 7) attained relatively low values in 1969 and during 1980s, when the lake level exceeded the outlet threshold (Fig. 2). Since 1990, the lowering of the lake level has led to a stepped increase of the ionic content, with a small decrease in the years 2005-2006. The analysis of the data has shown that, besides a concentration effect, a net accumulation of salts is occurring in the lake. The total amount of dissolved solids increased gradually from $24210^{6} \mathrm{~kg}$ in 1990 to $32510^{6} \mathrm{~kg}$ in 2006 , with an accumulation rate of about $3.5 \pm 0.610^{6} \mathrm{~kg} \mathrm{y}^{-1}$, as estimated by linear regression $\left(r^{2}=0.72 ; p<0.001 ; \mathrm{N}=16\right)$. In the same period, the content of $\mathrm{Cl}^{-}$increased by about $1.5610^{6} \mathrm{~kg} \mathrm{y}^{-1}\left(r^{2}=0.96 ; p<0.001 ; \mathrm{N}=16\right)$, whereas the accumulation rate of sulphate amounted to $0.3710^{6}$ $\mathrm{kg} \mathrm{y}^{-1}\left(r^{2}=0.76 ; p<0.001 ; \mathrm{N}=16\right)$.

Unfortunately, an exhaustive description of the historical changes occurred to the ionic composition of lake water was not feasible, due mainly to the incompleteness of the available data about cations. For the major anions, a triangular plot (Fig. 8) shows the enrichment in chlorides and sulphates in the period 1969-2006, which moved the water from anion field $8\left[\mathrm{Cl}-\mathrm{CO}_{3}\right]$ in 1969 , through to anion field $7\left[\mathrm{Cl}-\mathrm{CO}_{3}-\right.$ $\left.\left(\mathrm{SO}_{4}\right)\right]$ up to the boundary of anion field $3\left[\mathrm{Cl}-\left(\mathrm{CO}_{3}\right)-\right.$ $\left.\left(\mathrm{SO}_{4}\right)\right]$, according to the scheme of nomenclature adopted by Euster \& Hardie (1978).

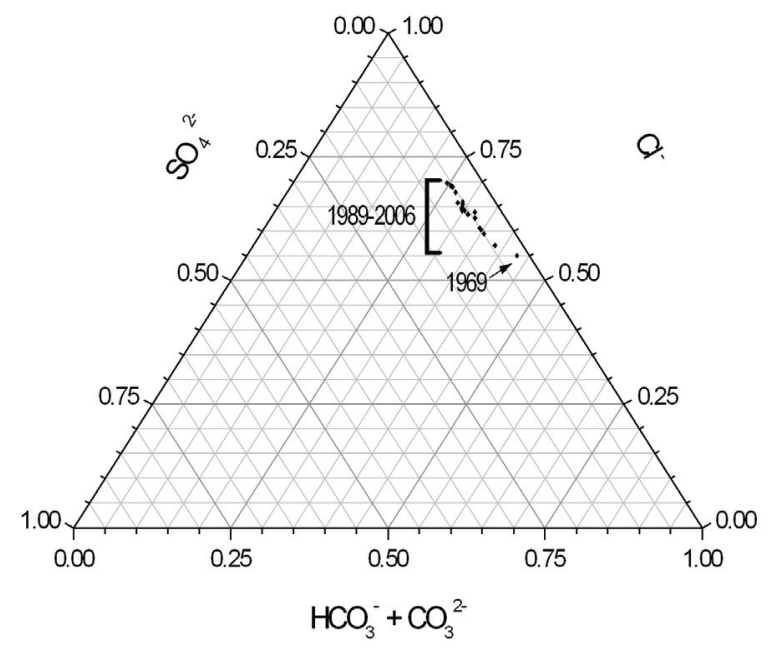

Fig. 8. Brine composition changes in Lake Trasimeno during the last forty years in terms of the major anions (as molar fraction).

A more detailed pathway of change in the ionic composition of the waters can be traced by comparing data collected in several distinct surveys. As can be seen from table 1 , the total concentration of anions and cations (whose difference was, in most cases, acceptable, i.e., less than \pm 0.2 meq $\mathrm{L}^{-1}$ ) progressively increased during the periods in which the water level lay below the outlet threshold (periods 1970-1975 and 1988-2006). To this trend contributed mostly the change in the concentration of the more conservative ions $\mathrm{Cl}^{-}$, $\mathrm{SO}_{4}^{2-}, \mathrm{Na}^{+}, \mathrm{K}^{+}$), but also the change in $\mathrm{TA}$, calcium and magnesium. The increase of $\mathrm{Ca}$ is particularly significant, as it has been shown (Giovanardi et al. 1995a) to 
Tab. 1. Ionic composition of water samples collected at surface in Lake Trasimeno in spring months of different years. ${ }^{\text {(a) }}$ height above the outlet threshold; (b) "explicitly conservative alkalinity" calculated from the charge imbalance: $\mathrm{TA}^{\mathrm{ec}}=$ $\left[\mathrm{Na}^{+}\right]+2\left[\mathrm{Mg}^{2+}\right]+2\left[\mathrm{Ca}^{+}\right]+\left[\mathrm{K}^{+}\right]-\left[\mathrm{Cl}^{-}\right]-2\left[\mathrm{SO}_{4}{ }^{2-}\right]$ (Zeebe \&Wolf-Gladrow 2001); ${ }^{\text {(c) }}$ total concentration of $\mathrm{Ca}^{2+}$ and $\mathrm{Mg}^{2+}$ estimated from hardness data; ${ }^{(d)}$ estimated from chloride concentration by assuming concentration ratios $\mathrm{Na} / \mathrm{Cl}=0.94$ and $\mathrm{K} / \mathrm{Cl}=0.021$ (Peruzzi et al. 2005).

\begin{tabular}{|c|c|c|c|c|c|c|c|c|c|c|c|c|c|c|}
\hline Year & $\begin{array}{c}\text { Water level } \\
\mathrm{cm}^{\text {(a) }}\end{array}$ & $\begin{array}{l}\text { Cond. } \\
25^{\circ} \mathrm{C} \mu \mathrm{S} \mathrm{cm}{ }^{-1}\end{array}$ & $\mathrm{pH}$ & $\begin{array}{c}\mathrm{Cl}^{-} \\
\text {meq L } \mathrm{L}^{-1}\end{array}$ & $\begin{array}{l}\mathrm{SO}_{4}{ }^{2-} \\
\text { meq L }{ }^{-1}\end{array}$ & $\begin{array}{c}\text { TA } \\
\text { meq } L^{-1}\end{array}$ & $\begin{array}{c}\mathrm{Ca}^{2+} \\
\text { meq L } \mathrm{L}^{-1}\end{array}$ & $\begin{array}{l}\mathrm{Mg}^{2+} \\
\text { meq L }\end{array}$ & $\begin{array}{c}\mathrm{Na}^{+} \\
\text {meq } \mathrm{L}^{-1}\end{array}$ & $\begin{array}{c}\mathrm{K}^{+} \\
\text {meq } \mathrm{L}^{-1}\end{array}$ & $\begin{array}{l}\text { Anions } \\
\text { meq } L^{-1}\end{array}$ & $\begin{array}{l}\text { Cations } \\
\text { meq L } L^{-1}\end{array}$ & $\begin{array}{l}\mathrm{TA}^{\mathrm{ec}(\mathrm{b})} \\
\mathrm{meq} \mathrm{L}^{-1}\end{array}$ & $\begin{array}{c}\text { Ionic strength } \\
\mathrm{M}\end{array}$ \\
\hline 1969 & 30 & 748 & 8.68 & 3.63 & 0.34 & 2.80 & 1.04 & 2.26 & $3.41^{(\mathrm{d})}$ & $0.08^{(\mathrm{d})}$ & 6.77 & 6.79 & 2.82 & 0.010 \\
\hline 1973 & -30 & 843 & 9.00 & 4.60 & 0.50 & 2.80 & \multicolumn{2}{|c|}{$3.66^{(\mathrm{c})}$} & $4.32^{(\mathrm{d})}$ & $0.10^{(\mathrm{d})}$ & 7.90 & 8.08 & 2.98 & 0.011 \\
\hline 1975 & -86 & 1084 & 8.26 & 5.52 & 0.50 & 3.90 & \multicolumn{2}{|c|}{$4.86^{(\mathrm{c})}$} & $5.19^{(\mathrm{d})}$ & $0.12^{(\mathrm{d})}$ & 9.92 & 10.16 & 4.14 & 0.015 \\
\hline 1981 & 42 & 856 & 8.33 & 4.23 & 0.62 & 3.75 & 1.86 & 2.54 & $3.97^{(\mathrm{d})}$ & $0.09^{(\mathrm{d})}$ & 8.60 & 8.46 & 3.61 & 0.013 \\
\hline 1984 & 2 & 878 & 8.60 & 4.65 & 0.81 & & 1.80 & 2.47 & 4.61 & 0.14 & & 9.02 & 3.55 & \\
\hline 1989 & -10 & 881 & 8.66 & 5.16 & 0.84 & 3.70 & 2.00 & 2.76 & $4.85^{(\mathrm{d})}$ & $0.11^{(\mathrm{d})}$ & 9.70 & 9.72 & 3.72 & 0.014 \\
\hline 1993 & -43 & 1053 & 8.53 & 6.06 & 1.12 & 4.00 & 2.00 & 3.04 & $5.70^{(\mathrm{d})}$ & $0.13^{(\mathrm{d})}$ & 11.18 & 10.86 & 3.68 & 0.016 \\
\hline 2005 & -119 & 1440 & 8.52 & 8.98 & 1.41 & 3.56 & 2.03 & 2.93 & 8.57 & 0.23 & 13.95 & 13.76 & 3.37 & 0.018 \\
\hline
\end{tabular}

Tab. 2. Median value and range of variation of reactive silica, nitrates, nitrites and ammonia

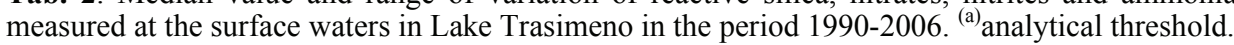

\begin{tabular}{lcccc}
\hline & $\begin{array}{c}\text { Reactive silica } \\
\mathrm{mg} \mathrm{SiO}_{2} \mathrm{~L}^{-1}\end{array}$ & $\begin{array}{c}\mathrm{NO}_{3}^{-} \\
\mathrm{mg} \mathrm{N} \mathrm{L}^{-1}\end{array}$ & $\begin{array}{c}\mathrm{NO}_{2}^{-} \\
\mathrm{mg} \mathrm{N} \mathrm{L}^{-1}\end{array}$ & $\begin{array}{c}\mathrm{NH}_{3} \\
\mathrm{mg} \mathrm{N} \mathrm{L}^{-1}\end{array}$ \\
\hline $\begin{array}{l}\text { Median value } \\
\text { Range of variation }\end{array}$ & $\begin{array}{c}2.20 \\
0.065-5.50\end{array}$ & $\begin{array}{c}0.01^{(\mathrm{a})} \\
0.01^{\text {(a) }}-0.41\end{array}$ & $0.003^{(\mathrm{a})}$ & $0.043^{\text {(a) }}-0.029$ \\
\hline
\end{tabular}

be controlled by the solubility of calcite. The almost constant ratio $\mathrm{Ca} / \mathrm{Mg}=0.7$ observed in the more recent samples (after 1980) also suggests that the concentration of magnesium is controlled by the solubility of $\mathrm{Mg}-\mathrm{Ca}$ mixed carbonates. The charge imbalance caused by the increase of $\mathrm{Ca}$ and $\mathrm{Mg}$ was partially balanced by sulphates (to a greater extent in the more recent samples) and by TA, whose observed values are consistent with the values of the explicitly conservative alkalinity $\left(\mathrm{TA}^{\mathrm{ec}}\right.$, Zeebe \&Wolf-Gladrow 2001), calculated from the charge imbalance (Tab. 1).

About other important ions, such as reactive silica, nitrates, nitrites and ammonia, no significant trends of variation emerged from the examination of the data series collected by A.R.P.A. Umbria in the period 19902006, a summary statistics of which is reported in table 2 .

\section{DISCUSSION}

From the analysis of the available series of data, several meteorological and water quality variables have shown to vary significantly during the period 1950-2006 in the basin of Lake Trasimeno. Four main aspects deserve a thorough discussion, which will be done with the aim of explaining the observed patterns and predicting possible changes within the current scenarios of climate change.

\subsection{Meteorology and hydrology}

The results of the analysis of the fifty-year series of meteorological data shows that the changes observed in the areas of Lake Trasimeno are in a substantial agreement with previous observations (Brunetti et al. 2004; Brunetti et al. 2006). As far as precipitation is concerned, three main negative anomalies have been observed in Central Italy (the years '40-50, the first half of the 1970s and after 1990), in which annual precipitation remained below the 1860-2000 average for several years. These drought phases mostly reflected the fluctuations in spring precipitation (MAM) and, for the more recent phase, in winter precipitation (DJF). The analysis of the monthly precipitation here performed has shown that the period 1989-2006 differed significantly from the previous ones, the difference being mostly due to the reduction in the amount of precipitation during the first half of the year, with the exception of April. In contrast with the results of Brunetti et al. (2006), our examination did not show a clear reduction in the total number of rainy days per year, or an increase in extreme events during the last 50 years.

The trends of maximum and minimum temperature in the areas of Lake Trasimeno also turned out to be consistent with those detected in Peninsular Italy, for which the recent positive anomaly exceeded $1{ }^{\circ} \mathrm{C}$ at the end of the $20^{\text {th }}$ Century. At a seasonal level, Brunetti et al. (2006) found that the anomalies were steeper in spring and summer than in autumn and winter. The analysis of the monthly series here reported has confirmed this conclusion, showing also that the variations are significant for late spring and summer months, with particular reference to May and June. The decadal rate of warming observed for Lake Trasimeno $\left(0.33{ }^{\circ} \mathrm{C} \mathrm{dec}-\right.$ $\left.\mathrm{ade}^{-1}\right)$ is also consistent with the estimate reported by the IPCC for the land-surface temperature in the Northern Hemisphere. Although showing an analogous seasonal trend, the water temperature at the surface in Lake Trasimeno has undergone a more marked increase $\left(0.65^{\circ} \mathrm{C}\right.$ decade $^{-1}$ ) during the period 1980-2005, which is comparable to that observed in other lakes of the Mediterranean areas (e.g., Lake Maggiore: Ambrosetti et al. 2006). 
The analysis of solar radiation data offers a possible partial explanation about the immediate causes producing the observed patterns of variation in temperature. The annual solar irradiance has shown a slightly increasing trend during the $1988-2006$ period $(+2 \%$ as an overall increase), which becomes more significant when considering the late-spring and early-summer months (April-July). As previously shown, in these months the most significant change in air and water temperatures was also observed. This correspondence suggests that the increase in the radiative forcing may have produced an appreciable effect on air and, especially, on water temperature, particularly in the period of maximum insolation. The observed changes can be reasonably interpreted as a consequence of a reduction in the cloud cover. A highly significant negative trend in yearly and seasonal average cloud amount all over Italy (1951-1996) has been evidenced by Maugeri et al. (2001), who related this phenomenon to the increasing frequency of anticyclones over Southern Europe, due to the strengthening of the North Atlantic Oscillation.

The simultaneous and significant change in the main meteorological forcing variables can be expected to have produced appreciable modifications on the energy and hydrological balance of the lake. In fact, as emerges from the application of a model previously calibrated for Lake Trasimeno by Ludovisi \& Poletti (2003), the terms of the energy budget show an appreciable variation during the period 1988-2006, with the shortwave term (incoming) increasing by $1.5 \%$, the longwave term (outgoing) increasing by $2.5 \%$, the sensible heat loss increasing by about $12 \%$ and the evaporation/condensation loss increasing by about $1.5 \%$. In hydrological terms, these changes result in an estimated increase of $30 \mathrm{~mm}$ of the annual evapora-transpiration from the lake. Although seemingly negligible, such an increase makes evapo-transpiration losses more likely to exceed water supplies by precipitation, thus making a recover from drought more difficult.

\subsection{Salinity}

An analysis of the forty-year observations has shown that a rapid accumulation of salt is occurring in Lake Trasimeno since 1989, as a consequence of the emergence of evaporative conditions (closed basin and low precipitations). The lake can still be classified as a freshwater system (TDS $=0.8 \%$ in 2006), but, on the basis of the observed accumulation rate $\left(3.510^{6} \mathrm{~kg} \mathrm{y}^{-1}\right)$, and by taking the average water level of 2006 as a reference, the lake can be predicted to reach the boundary value of 5\% - the threshold usually adopted for distinguishing fresh from saline waters (Beadle 1974) - in about 5 centuries. Obviously, this expectation must be revised by defect if the present drought phase would be exacerbated.

The observed accumulation rate of salts is only partially explained by the load carried by rainwater. From the data collected at the ENEL-DCO station located at Monte Peglia (Mosello 1991, 1993a, 1993b; Mosello \& Morselli 1992), the average ionic composition of rain in the period 1988-1992 was: $\mathrm{Cl}^{-}=2.11 \mathrm{mg} \mathrm{L}^{-1} ; \mathrm{SO}_{4}{ }^{2-}$ $=2.59 \mathrm{mg} \mathrm{L}^{-1} ; \mathrm{NO}_{3}{ }^{-}=2.68 \mathrm{mg} \mathrm{L}^{-1} ; \mathrm{Ca}^{2+}=2.69 \mathrm{mg} \mathrm{L}^{-1}$; $\mathrm{Mg}^{2+}=0.3 \mathrm{mg} \mathrm{L}^{-1} ; \mathrm{Na}^{+}=1.31 \mathrm{mg} \mathrm{L}^{-1} ; \mathrm{K}^{+}=0.34 \mathrm{mg}{ }^{\mathrm{L}-1}$; $\mathrm{NH}_{4}^{+}=0.54 \mathrm{mg} \mathrm{L}{ }^{-1} ; \mathrm{pH}=5.47$. By adopting the recently revised annual average runoff coefficient of 0.28 (Dragoni 2004), the average annual water inflow in the period 1987-2006 can be approximately estimated as $12510^{6} \mathrm{~m}^{3} \mathrm{y}^{-1}, 4810^{6} \mathrm{~m}^{3} \mathrm{y}^{-1}$ of which comes from the catchment basin. On the basis of these data, the annual atmospheric loading of the most conservative ions can be estimated as: $\mathrm{Cl}^{-}=0.2610^{6} \mathrm{~kg} \mathrm{y}^{-1} ; \mathrm{SO}_{4}{ }^{2-}=0.3310^{6}$ $\mathrm{kg} \mathrm{y}^{-1} ; \mathrm{Mg}^{2+}=0.0410^{6} \mathrm{~kg} \mathrm{y}^{-1} ; \mathrm{Na}^{+}=0.1610^{6} \mathrm{~kg} \mathrm{y}^{-1} ; \mathrm{K}^{+}$ $=0.0410^{6} \mathrm{~kg} \mathrm{y}^{-1}$ ), which amount to about $0.8310^{6} \mathrm{~kg}$ $\mathrm{y}^{-1}$. As can be seen, the last value is about four times lower than the annual increase of TDS estimated by the accumulation curve. Similarly, the estimated atmospheric loading of chloride is considerably lower than that obtained from the accumulation curve $\left(1.5610^{6} \mathrm{~kg}\right.$ $\left.\mathrm{y}^{-1}\right)$, whereas the value obtained for sulphates is fairly well in agreement with the accumulation in the last two decades $\left(0.3710^{6} \mathrm{~kg} \mathrm{y}^{-1}\right)$. The relatively low accumulation of sulphate can be explained by considering that this anion is less conservative than chloride in conditions which favour the activity of sulphate-reducing bacteria, as in the organic-rich muds of Lake Trasimeno (M.A.R.U. 1994).

However, the ionic load from lake's watershed is certainly higher than that due to atmospheric deposition. As shown by several observations performed in 20052008 (Selvaggi, pers. comm.) on water samples collected in the Anguillara channel (the main tributary of the lake, which collects waters from about $30 \%$ of the catchment basin) the concentration of the major conservative ions is usually one order of magnitude higher than that of the rainwater. In particular, by taking a concentration of about $40 \mathrm{mg} \mathrm{L}^{-1}$ as representative of the concentration of chloride, a total load of $0.710^{6} \mathrm{~kg} \mathrm{y}^{-1}$ can be calculated from the Anguillara channel. Extending the calculation to the whole catchment basin, the total load of chloride can be estimated at about $1.710^{6}$ $\mathrm{kg} \mathrm{y}^{-1}$, which roughly matches the value obtained by the accumulation curve. Although inaccurate, this calculation suggests that the most significant load of salts in the lake comes from the watershed, as a consequence of weathering processes or wastewater discharge.

\subsection{Alkalinity and $p H$}

The analysis of mean and extreme annual values of $\mathrm{pH}$ and TA suggested that the buffering capacity of the waters has significantly varied in Lake Trasimeno during last forty-years period, the main changes in TA being related to the changes in the ionic composition of the waters. The strict link between TA and salinity is well known for surface waters and, particularly, open 
ocean waters, where TA is typically found to behave conservatively (Millero et al. 1998). The reason of this connection relies on the fact that TA is inherently associated with the charge balance (Stumm \& Morgan 1970; Zeebe \&Wolf-Gladrow 2001): in surface waters, the sum of the charges of the major cations is not exactly balanced by the major (non-carbonatic) anions, and this charge imbalance is mainly balanced by the anions of carbonic acid, the main contributors to TA. It follows that the surface TA of aquatic systems is mainly controlled by ionic composition, although biological processes can exert a little direct effect by removing or releasing nutrients (Brewer \& Goldman 1976; Redfield et al. 1963). TA is therefore expected to vary in water systems experiencing changes in the ionic composition, such as in lakes subjected to evaporative conditions. The evolution of the chemical composition of such systems is very complex and largely dependent on the specific lithological characteristic of the lake basin and the intensity of weathering processes. In general, as a consequence of the unbalanced concentration of ions, TA is observed to increase with salinity in freshwater (e.g., Lake Chad, Carmouze et al. 1983) and saline (Euster \& Hardie 1978) lakes subjected to drought. An increase in TA and base cations $\left(\mathrm{Ca}^{2+}, \mathrm{Mg}^{2+}, \mathrm{Na}^{+}, \mathrm{K}^{+}\right)$has also been observed in several freshwater lakes located in mountain areas that are experiencing a drying and warming climate (Schildler et al. 1990; Wögrath \& Psenner 1995; Rogora et al. 2003). In mountain lakes, the observed increase in solute content and alkalinity has been essentially attributed to the reduction in the renewal rate of the waters (Schindler et al. 1990) and to the increasing weathering of easily soluble salts such as calcium and magnesium sulphate from the catchment basin, due to increasing temperature and reduced snow cover (Rogora et al. 2003).

In Lake Trasimeno, a progressive increase in TA was observed during the periods in which the lake experienced phases of salinisation due to the occurrence of evaporative conditions (periods1970-1975 and 19882005). In both periods, the increase in TA has been shown to be consistent with what expected on the basis of the changes in the charge balance of the major noncarbonatic ions, which was mostly due to the unbalanced increase of sulphates and alkaline earth ions $\mathrm{Ca}$ and $\mathrm{Mg}$.

Whereas the increase in the concentration of sulphate can be mostly explained in terms of a progressive accumulation and concentration of external inputs, the explanation of the increase in calcium and magnesium is more problematic, since these ions appear to be mostly controlled by the solubility of calcite (Giovanardi et al. 1995a) and Ca-Mg mixed carbonates. Among the possible explanations, the effect due to the ionic strength must certainly be taken into account, as this factor significantly affects the solubility of alkaline earth carbonates. For example, it can be calculated that an increase in the ionic strength from 0.01 to $0.02 \mathrm{M}$, which is comparable in extent to the range of variation observed in Lake Trasimeno (Tab. 1), is able to enhance the solubility of calcite by about $20 \%$.

As a whole, the pattern of evolution of $\mathrm{TA}$ and $\mathrm{pH}$ appears to be dominated by the effects of increasing salt content and differential concentration of ionic species during drought phases. Therefore, further changes have to be expected in Lake Trasimeno in the perspective offered by the current regional scenario of increasing temperature and decreasing precipitation, acidity and sulphate content in atmospheric depositions (Rogora et al. 2006), to which the impact of local water and wastewater management has to be added. However, the global effects of such a multiple forcing is rather unpredictable, as it strictly depends on which facet (hydrology, atmospheric input, weathering) will play the prominent role.

\subsection{Trophic state and water transparency}

The trophic classification of Lake Trasimeno has long been controversial (Ludovisi \& Poletti 2003): according to the OECD's criteria (Vollenweider \& Kerekes 1982), Lake Trasimeno has been classified as mesotrophic (Giovanardi et al. 1995b), whereas on the basis of Vollenweider-Dillon's phosphorus loading model (Vollenweider 1976) and Hillbrich-Ilkowska's method (Hillbricht-Ilkowska 1977), the lake has been classified as eutrophic (Mearelli et al. 1981; M.A.R.U. 1994; Hamza et al. 1995).

The analysis of historical data reported here has shown that, on the basis of total phosphorus and chlorophyll- $a$ concentration only, the lake has lain around the boundary values which separates the mesotrophic from the eutrophic class, according to the OECD's criteria. Therefore, the classification of the lake based on these data can easily shift from one class to the other, depending on the year being considered. On the basis of the historical data of TP concentration, however, no significant change has been envisaged for the trophic conditions of the lake over the last forty years, in spite of the significant phosphorus loading coming from the watershed (40 10 $0^{6} \mathrm{~g} \mathrm{y}^{-1}$ : Giovanardi et al. 1995b). Such a loading is expected to accumulate in the lake waters, particularly during periods when the renewal of the water is reduced, unless some natural mechanism of removal is working. According to Giovanardi et al. (1995a), several precipitation processes (which involve the formation of mixed crystals or surface complexes, as well as absorption on clay particles) can contribute to removing phosphorus and control the concentration of SRP in the water column. This hypothesis is supported by theoretical calculations (Ludovisi 2009), which show that the precipitation of hydroxyapatite $\left[\mathrm{Ca}_{5} \mathrm{OH}\left(\mathrm{PO}_{4}\right)_{3}\right]$ can limit the concentration of SRP to $1-4 \mu \mathrm{g} \mathrm{L}^{-1}$ in a simplified calcareous lake at equilibrium. 
By contrast, water transparency has shown very important fluctuations during the last forty years, which appear to be strictly connected with the water level. The analysis of historical data here reported has confirmed that the Secchi depth is poorly correlated with total phosphorus and chlorophyll- $a$ concentration, suggesting that both seasonal and long terms variations in water transparency cannot be interpreted in terms of variation in the trophic state. In fact, the Secchi depth has often been considered a non-reliable indicator of the trophic conditions in Lake Trasimeno (see, e.g., Giovanardi et al. 1995b), because it is supposed to be strongly affected by the presence of sediment particles suspended in the water column. This hypothesis is supported by the high content of total suspended solids (up to $466 \mathrm{mg} \mathrm{L}^{-1}$ - mean value $27 \mathrm{mg} \mathrm{L}^{-1}$ ) found in water samples collected monthly in front of the drinking plant of Castiglione del Lago in the period 1996-2004, which turns out to be also significantly related to wind intensity, as emerged by plotting them against the wind speed (as daily mean of the data collected at the S.I.G.L.A. meteorological station n. 2). The relation is fairly well described by the allometric function: TSS $=$ $11.1+0.106 \mathrm{~W}^{3.23}(r=0.70 ; \mathrm{N}=92)$, where TSS are the total suspended solids $\left(\mathrm{mg} \mathrm{L}^{-1}\right)$ and $\mathrm{W}$ the wind speed $\left(\mathrm{m} \mathrm{s}^{-1}\right)$. Regarding the composition of TSS, the analysis of settling material in sediment traps placed in the central areas of the lake in July 1997 (Ludovisi, unpublished data) shows that the most important fraction was inorganic $(57 \%$ at $1 \mathrm{~m}, 81 \%$ at $2 \mathrm{~m}$ and $85 \%$ at $3 \mathrm{~m}$ depth).

These data suggest that a significant amount of suspended material is raised from the superficial layer of the bottom sediments to the water column by windinduced circulation and waves, and therefore, that wind conditions can strongly affect the turbidity of the waters in Lake Trasimeno. As shown by Scheffer (1998), suspended sediments have a predominant effect on the turbidity and, particularly, on the Secchi depth in shallow lakes, especially in the case of large, wind-exposed lakes where sediments mostly consist of easily resuspendable clay, as in Lake Trasimeno (M.A.R.U. 1994). Furthermore, this effect is expected to increase as the thickness of the water column decreases, as evidenced by in-field observations and wave resuspension models. Wallsten \& Forsgren (1989) described the effect of water lowering on water turbidity in the very shallow Lake Tänmaren, emphasizing that both increasing phytoplankton density and resuspended sediments contributed strongly to the reduction of water transparency. Carper \& Bachman (1984) put forward a resuspension model according to which the fraction of lake surface where resuspension occurs $(\alpha)$ is an increasing function of the wind speed and fetch, and a decreasing function of lake depth in a hypothetical square lake of constant depth. When calculating $\alpha$ for Lake Trasimeno by assuming a constant wind speed of $10 \mathrm{~km} \mathrm{~h}^{-1}$ and differ- ent values for the depth of the lake, it may be found that $\alpha$ varies strongly in the region of interest $(0.36$ at $6 \mathrm{~m}$, 0.77 at $4 \mathrm{~m}$ and 0.95 at $2 \mathrm{~m}$ of depth). This suggests that in the range of variation of lake depth observed over the last century (Fig. 2), the resuspension of sediment by wave action has strongly affected the amount of suspended solids in the water, thus explaining the observed fluctuations of water transparency in relation to lake depth.

\section{CONCLUSIONS}

The results show that several significant changes have occurred during the last fifty years on the water quality of Lake Trasimeno, which are mostly related to the variations in the meteorological regime. The most critical issues are certainly related to the effect of reduced precipitation and increasing temperature on the water balance of the lake, which are causing a severe drought on the lake (about $-20 \%$ in volume during the last two decades). The present phase is likely to become exacerbated in the future, if we take into account IPCC projections (IPCC 2007). For Southern Europe and Mediterranean, the IPCC predicts, for the current century, a change of $+3.5{ }^{\circ} \mathrm{C}$ for air temperature and $-12 \%$ for precipitation (median values on 21 models assumed on the basis of the A1B scenario). If this scenario comes to pass, it is very likely that evaporative water losses from Lake Trasimeno will persistently exceed water supplies by precipitation in the near future, thus accelerating the draining of the lake. As the impoundment of the lake progresses, a worsening of the water quality, with particular reference to water transparency and salt content, have to be expected in the immediate future, but catastrophic transitions, sensu Scheffer (1998), may also be expected as a consequence of an increasing availability of nutrients in the water column, due to the reduced dilution of wastewaters and reduced thickness of the water column. Eutrophication-like responses (Visconti et al. 2008) can be also expected in the lake as a consequence of the warming of lake waters.

The realisation of a still-in-progress project of water transfer from the Tiber River basin for agricultural needs (which amount to about $30 \mathrm{Mm}^{3} \mathrm{y}^{-1}$, corresponding to about $250 \mathrm{~mm} \mathrm{y}^{-1}$ in terms of water level reduction; Morozzi et al. 1998) will certainly contribute to alleviating the hydrological crisis of the lake, although the ecological impact of such an intervention has not been evaluated yet.

In conclusion, the fate of Lake Trasimeno is now, much more than in the past, entrusted to humankind and to its capacity of moderating, both at a local and global scale, the impact of its activities. The present study also emphasises the importance of shallow water systems as "sentinel environments" in relation to global and regional climate change, and stimulates the research in this field, which could strongly contribute to depict the complex mosaic concerning the effects of global change on ecological systems. 


\section{ACKNOWLEDGEMENTS}

The authors are very grateful to the Hydrographic and Oceanographic Office of the Lazio Region for his cooperation in accessing databases. The Regional Environmental Protection Agency (A.R.P.A. Umbria) and the Province of Perugia are also acknowledged for making available environmental data. Special thanks are addressed to Ermanno Gambini and Walter Dragoni for useful discussion of hydrological and historical issues, and to Pompeo Calderoni for his generous help in tracing historical data. The authors also express their gratitude to the anonymous referees for their suggestions and criticisms, that greatly contribute to improve the quality of the paper. The research was financially supported by National funds F.I.S.R. (Fondo Integrativo Speciale per la Ricerca) within the M.I.C.E.N.A. (Modello Integrato per l'Evoluzione degli Ecosistemi Naturali e Agricoli in relazione ai cambiamenti climatici nell'area mediterranea) project.

\section{REFERENCES}

Ambrosetti, W., L. Barbanti \& A. Rolla. 2006. The climate of Lake Maggiore during the last fifty years. J. Limnol., 65: 1-62.

APAT-IRSA- CNR. 2003. Metodi analitici per le acque. Manuali e libri guida 29. Agenzia per la Protezione dell'ambiente e per i Servizi Tecnici, Roma: 1149 pp.

Balogh, C., I.B. Muskó, L.G. Tóth \& L. Nagy. 2008. Quantitative trends of zebra mussels in Lake Balaton (Hungary) in 2003-2005 at different water levels. Hydrobiologia, 613: 57-69.

Bates, B.C., Z.W. Kundzewicz, S. Wu \& J.P. Palutikof. 2008. Climate Change and Water. Technical Paper of the Intergovernmental Panel on Climate Change, IPCC Secretariat, Geneva: $210 \mathrm{pp}$.

Beadle, L.C. 1974. The Inland waters of tropical Africa. Longman, London: $365 \mathrm{pp}$.

Beeton R.J.S., K. Buckley, G.J. Jones, D. Morgan, R.E. Reichelt \& D. Trewin. 2006. Australia State of the Environment 2006, Independent Report to the Australian State of the Environment Committee. Canberra. Website: http:// www.environment.gov.au/soe/2006/publications/index.html.

Brewer, G. \& J.C. Goldman. 1976. Alkalinity changes generated by phytoplankton growth. Limnol. Oceanogr., 21: 108-117.

Brunetti, M., L. Buffoni, F. Mangianti, M. Maugeri, F. Monti \& T. Nanni. 2004. Temperature, precipitation and extreme event during the last century in Italy. Global Planet. Change, 40: 141-149.

Brunetti, M., M. Maugeri, F. Monti \& T. Nanni. 2006. Temperature and precipitation variability in Italy in the last two centuries from homogenised instrumental time series. Int. J. Climatol., 26: 345-381.

Budyko, M. I. 1974. Climate and life. Academic press, New York: 508 pp.

Carmouze, J.P., J.M. Chantraine \& J. Lemoalle. 1983. The lacustrine environment and its evolution - Physical and chemical characteristics of the waters. In: J.P. Carmouze, J.R. Durand \& C. Leveque (Eds), Lake Chad - ecology and productivity of a shallow tropical system. Kluwer Academic Publisher Group, The Hague: 65-94.

Carper, G.L. \& R.W. Bachmann. 1984. Wind resuspension of sediments in a prairie lake. Can. J. Fish. Aquat. Sci., 41: 1763-1767.

CNR-IRSA. 1994. Metodi analitici per le acque. Quaderno 100. Istituto per la Ricerca sulle Acque, Roma: 342 pp.
Colley, J. 2004. Drought Preparedness Council Biennium Report 2003-2004. Governor's Division of Emergency Management, Austin, Texas.

Craddock, J.M. 1979. Methods of comparing annual rainfall records for climatic purposes. Weather, 34: 332-346.

Deffenu, L. \& W. Dragoni. 1978. Idrogeologia del Lago Trasimeno. Geologia Applicata e Idrogeologia, 13: 11-67.

Di Giovanni, M.V., F.S. Gianotti, L. Mantilacci \& O. Tiberi. 1974. Prime informazioni su nutrienti N, P e produttività del Lago Trasimeno. Riv. Idrobiol., 13: 281-360.

Dragoni W., C. Evangelisti, L. Gnucci \& D. Valigi. 2003. Impact of climatic changes on hydrological systems: the case of Lake Trasimeno (Central Italy). Geophys. Res. Abstr. 5, EGS-AGU-EUG Joint Assembly, Nice, France, April 2003.

Dragoni, W. 1982. Idrogeologia del Lago Trasimeno: sintesi, problemi, aggiornamenti. Geogr. Fis. Dinam. Quat., 5: 192-206.

Dragoni, W. 2004. Il Lago Trasimeno e le variazioni climatiche. Provincia di Perugia: $60 \mathrm{pp}$ (in Italian with English transl.).

Euster, H.P. \& L.A. Hardie. 1978. Saline lakes. In: A. Lerman (Ed.), Lakes. Springer-Verlag, New York: 237-239.

Franconi, U., M. Mossone, F. Blasi, A. Burchia \& W. Galinari. 1987. Indagini chimiche e chimico-fisiche delle acque del Lago Trasimeno. Atti del Convegno: La tutela dell'ambiente lacuale del Lago Trasimeno. Perugia, 8-9 marzo 1985. Provincia di Perugia: 61-91.

Furey, P.C., R.N. Nordin \& A. Mazumder. 2006. Littoral benthic macroinvertebrates under contrasting drawdown in a reservoir and a natural lake. J.N. Am. Benthol. Soc., 25: 19-31.

Gambini, E. 2000. I villaggi sommersi del Lago Trasimeno. Quaderni del Museo della Pesca 5. Edizioni Era Nova, Perugia: $117 \mathrm{pp}$.

Gambini, E., 1995. Le oscillazioni di livello del Lago Trasimeno. Quaderni del Museo della Pesca 2, Edizioni Era Nova, Perugia: $139 \mathrm{pp}$.

Gianotti, F.S., L. Mantilacci, M. Mearelli \& O. Tiberi. 1982. Physionomie physique et chimique du Lac Trasimène pendant la période 1969-79. Guide-Itineraire de l'Excursion Internationale de Phytosociologie en Itale Centrale (211 Jul. 1982). Università degli Studi di Camerino: 444-469.

Giovanardi, F., A. Poletti \& A. Micheli. 1995a. Indagini sulla qualità delle acque del Lago Trasimeno - Idrochimica. Acqua Aria, 5: 519-526.

Giovanardi, F., A. Poletti \& A. Micheli. 1995b. Indagini sulla qualità delle acque del Lago Trasimeno - Definizione dei livelli trofici. Acqua Aria, 6: 627-633.

Hamza, W., P. Pandolfi \& M.I. Taticchi. 1995. Planktonic interactions and their role in describing the trophic status of a shallow lake in Central Italy (Lake Trasimeno). Mem. Ist. ital. Idrobiol., 53: 125-139.

Hillbricht Ilkowska, A. 1977. Trophic relations and energy flow in pelagic plankton. Ekol. Pol., 3: 3-98.

ILEC-UNEP. 1989. Guidelines of lake management. In: Jørgensen, S.E., \& R.A. Vollenweider (Eds), Principles of lake management. International Lake Environment Committee Foundation. Otsu, Shiga, Japan: 199 pp.

IPCC. 2007: Climate Change 2007: The Physical Science Basis. Contribution of Working Group I to the Fourth Assessment Report of the Intergovernmental Panel on Climate Change [Solomon, S., D. Qin, M. Manning, Z. Chen, M. Marquis, K.B. Averyt, M. Tignor and H.L. Miller (Eds)]. Cambridge University Press, Cambridge, United Kingdom and New York, NY, USA: 996 pp.

Ludovisi A. \& A. Poletti. 2003. Use of thermodynamic indices as ecological indicators of the development state of lake ecosystems: 1. Entropy production indices. Ecol. Model., 159: 203-222.

Ludovisi, A. 1998. Approcci olistici applicati allo studio degli ecosistemi lacustri: il caso del Lago Trasimeno. PhD thesis. Università di Perugia: $152 \mathrm{pp}$. 
Ludovisi, A. 2009. Exergy vs information in ecological successions: Interpreting community changes by a classical thermodynamic approach. Ecol. Model., 220: 1566-1577.

M.A.R.U. 1994. Piano di Gestione per il Lago Trasimeno finalizzato al controllo dell'eutrofizzazione. Parte IV. Ministero dell'Ambiente e Regione Umbria.

Mannelli, G. \& P. Mancini. 1962. Forme di inquinamento delle acque del Lago Trasimeno. Riv. Idrobiol., 2: 113-126.

Mantilacci, L., M. Mearelli, G. Giovinazzo \& M. Lorenzoni. 1990. Accrescimento e alimentazione del latterino (Atherina boyeri Risso) del Lago Trasimeno. Riv. Idrobiol., 29: 309-327.

Maugeri, M., Z. Bagnati, M. Brunetti \& T. Nanni. 2001. Trends in Italian cloud amount, 1951-1996. Geophys. Res. Let., 28: 4551- 4554.

Mearelli, M. 1985. La pesca nel Lago Trasimeno: note ambientali e produttive del venticinquennio 1956-80. Umbria Economica, 3: 65-85.

Mearelli, M., M. Lorenzoni \& F. Ruffini. 1981. Determinazione dello stato trofico del Lago Trasimeno attraverso la valutazione indiretta dell'azoto e del fosforo. Riv. Idrobiol., 20: 571-587.

Mearelli, M., M. Lorenzoni \& L. Mantilacci. 1990. Il Lago Trasimeno. Riv. Idrobiol., 29: 353-389.

Millero, F.J., K. Lee \& M. Roche. 1998. Distribution of alkalinity in the surface waters of the major oceans. Mar. Chem., 60: 111-130.

Moretti, G.P. 1958. Il Lago Trasimeno (tre anni di studi idrobiologici) - Termica e chimismo del sistema: ossigeno-durezza-pH nelle acque del L. Trasimeno (marzo 1956 marzo 1957). Quaderni della Sezione Perugina della Società Italiana di Biologia Sperimentale, 21: 33-58.

Morozzi G., A. Poletti, M. Giombini, A. Ludovisi \& L. Poletti. 1998. Redazione di uno studio inteso alla individuazione di conoscenze, disequilibri ed azioni nel bacino del Lago Trasimeno. CESAR - Centro per lo sviluppo agricolo e rurale per Autorità di bacino del fiume Tevere.

Mosello, R. 1991. Rete italiana per lo studio delle deposizioni atmosferiche (RIDEP). Situazione degli studi sulla chimica delle deposizioni atmosferiche umide nel 1988 in Italia. Documenta Ist. ital. Idrobiol., 29: 42 pp.

Mosello, R. 1993a. Rete italiana per lo studio delle deposizioni atmosferiche (RIDEP). Situazione degli studi sulla chimica delle deposizioni atmosferiche umide nel 1991 in Italia. Documenta Ist. ital. Idrobiol., 42: 46 pp.

Mosello, R. 1993b. Rete italiana per lo studio delle deposizioni atmosferiche (RIDEP). Situazione degli studi sulla chimica delle deposizioni atmosferiche umide nel 1992 in Italia. Documenta Ist. ital. Idrobiol., 43: $42 \mathrm{pp}$.

Mosello, R. \& L. Morselli. 1992. Rete italiana per lo studio delle deposizioni atmosferiche (RIDEP). Situazione degli studi sulla chimica delle deposizioni atmosferiche umide nel 1989 in Italia. Documenta Ist. ital. Idrobiol., 33: 34 pp.

Orsomando, E. \& A. Catorci. 1991. Carta della vegetazione del comprensorio Trasimeno. Editrice Grafica l'Etruria, Cortona.

Peruzzi, L., 2005. Gli acquiferi nel bacino del Lago Trasimeno: analisi delle caratteristiche idrogeologiche e idrogeochimiche per la valutazione dei rapporti con il corpo idrico lacustre e l'identificazione delle criticità ambientali. ARPA Umbria Monogr., 5: 21 pp.

Redfield, A.C., B.H. Ketchum \& F.A. Richards. 1963. The influence of organisms on the composition of seawater. In: M. N. Hill (Ed.), The Sea, vol. 2. Interscience, New York: 26-77.

Rogora, M., R. Mosello \& S. Arisci. 2003. The effect of climate warming on the hydrochemistry of alpine lakes. Water Air Soil Poll., 148: 347-361.
Rogora, M., R. Mosello, S. Arisci, M.C. Brizzio, A. Barbieri, R. Balestrini, P. Waldner, M. Scmhidt, M. Stähli, A. Thimonier, M. Kalina, H. Puxbaum, U. Nickus, E. Ulrich \& A. Probst. 2006. An overview of atmospheric deposition chemistry over the Alps: present status and long-term trends. Hydrobiologia, 562: 17-40.

Scheffer, M. 1998. Ecology of shallow lakes. Chapman \& Hall, London: $357 \mathrm{pp}$.

Schindler, D.W., K.G. Beaty, E.J. Fee, D.R. Cruickshnak, E.R. DeBruyn, D.L. Findlay, G.A. Linsey, J.A. Sheare, M.P. Stainton \& M.A. Turner. 1990. Effects of climate warming on lakes of the Central Boreal Forest. Science, 250: 967-970.

Stumm, W. \& J.J. Morgan. 1970. Aquatic Chemistry. Wiley, New York: $583 \mathrm{pp}$

Taticchi, M.I. \& O. Tiberi. 1980. Fauna macrobentonica e fattori fisici e chimici in prossimità dello sbocco di una piccola fogna nel Lago Trasimeno. Riv. Idrobiol., 19: 469-493.

Tiberi, O. 1980. Fluoruri e cloruri nel Lago Trasimeno. Riv. Idrobiol., 19: 37-60.

Tiberi, O. 1985. Lago Trasimeno. Confronto tra le condizioni fisiche e chimiche evidenziate in due periodi: 1969-70 e 1980-81. S.It.E. Atti, 5: 97-98.

Tiberi, O., M.I. Taticchi-Viganò \& M.V. Di Giovanni. 1971. Ragguagli sulle condizioni fisiche, chimiche, planctologiche del Lago Trasimeno (febbraio 1969 - febbraio 1970). Riv. Idrobiol., 10: 39-233.

Tiberi, O., M.N. Lollini, S. Monarca, A. Savino, G. Scassellati-Sforzolini, E. Aisa, P. Gattaponi, U. Franconi, F. Morini, M. Mossone \& G. Losito. 1973. Risultati di tre anni e mezzo di indagini sullo stato di inquinamento del Lago Trasimeno. Atti del Convegno: Iniziative per la difesa dell'ambiente in Umbria. Perugia, 29 Ottobre 1972. Regione dell'Umbria: 145-178.

Trevisan, R. 1978. Fluttuazione stagionale della densità e della biomassa fitoplanctonica del Lago Trasimeno. Riv. Idrobiol., 16: 297-329.

UNEP. 2006. Africa's Lakes: Atlas of Our Changing Environment. United Nations Environment Programme report. Website: http://www.unep.org/themes/Freshwater/Publications/index.asp.

Visconti, A., M. Manca \& R. de Bernardi. 2008. Eutrophication-like responses to climate warming: an analysis of Lago Maggiore (N. Italy) zooplankton in contrasting years. J. Limnol., 67: 87-92.

Vollenweider, R. \& J. Kerekes. 1982. Eutrophication of waters: monitoring, assessment and control. Tech. Rep. OECD. OECD, Paris.

Vollenweider, R.A. 1976. Advances in defining critical loading levels for phosphorous in lake eutrophication. Mem. Ist. ital. Idrobiol., 33: 53-83.

Wallsten, M. \& P.O. Forsgren. 1989. The effects of increased water level on aquatic macrophytes. J. Aquat. Plant Manage., 27: 32-37.

Wantzen, K.M., K.O. Rothhaupt, M. Mörti, M. Cantonati, L.G. Tóth \& P. Fisher. 2008. Ecological effects of waterlevel fluctuations in lakes: an urgent issue. Hydrobiologia, 613: $1-4$

Wögrath, S. \& R. Psenner. 1995. Seasonal, annual and longterm variability in the water chemistry of a remote high mountain lake: Acid rain versus natural change. Water Air Soil Poll., 85: 359-364.

Zeebe, R.E. \& D. Wolf-Gladrow. 2001. $\mathrm{CO}_{2}$ in seawater: equilibrium, kinetics, isotopes. Elsevier Science B.V., The Netherlands: $350 \mathrm{pp}$.

Received: June 2009

Accepted: November 2009 